\title{
Airborne characterization of smoke marker ratios from prescribed burning
}

\author{
A. P. Sullivan ${ }^{1}$, A. A. May ${ }^{1}$, T. Lee ${ }^{1}$, G. R. McMeeking ${ }^{1}$, S. M. Kreidenweis ${ }^{1}$, S. K. Akagi ${ }^{2}$, R. J. Yokelson ${ }^{2}$, \\ S. P. Urbanski ${ }^{3}$, and J. L. Collett Jr. ${ }^{1}$ \\ ${ }^{1}$ Colorado State University, Department of Atmospheric Science, Fort Collins, Colorado 80523, USA \\ ${ }^{2}$ University of Montana, Department of Chemistry, Missoula, MT 59812, USA \\ ${ }^{3}$ USDA Forest Service, Rocky Mountain Research Station, Fire Sciences Laboratory, Missoula, MT 59808, USA
}

Correspondence to: A. P. Sullivan (sullivan@atmos.colostate.edu)

Received: 7 April 2014 - Published in Atmos. Chem. Phys. Discuss.: 9 May 2014

Revised: 17 July 2014 - Accepted: 5 August 2014 - Published: 9 October 2014

\begin{abstract}
A Particle-Into-Liquid Sampler - Total Organic Carbon (PILS-TOC) and fraction collector system was flown aboard a Twin Otter aircraft sampling prescribed burning emissions in South Carolina in November 2011 to obtain smoke marker measurements. The fraction collector provided 2 min time-integrated offline samples for carbohydrate (i.e., smoke markers levoglucosan, mannosan, and galactosan) analysis by high-performance anion-exchange chromatography with pulsed amperometric detection. Each fire location appeared to have a unique $\Delta$ levoglucosan / $\Delta$ water-soluble organic carbon (WSOC) ratio $\left(\mathrm{RF} 01 / \mathrm{RF} 02 / \mathrm{RF} 03 / \mathrm{RF} 05=0.163 \pm 0.007 \mu \mathrm{g} \mathrm{C} \mu \mathrm{g}^{-1} \mathrm{C}\right.$, $\mathrm{RF} 08=0.115 \pm 0.011 \mu \mathrm{g} \mathrm{C} \mu \mathrm{g}^{-1} \mathrm{C}, \mathrm{RF} 09 \mathrm{~A}=0.072$

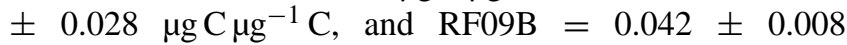
$\mu \mathrm{g} \mathrm{C} \mu \mathrm{g}^{-1} \mathrm{C}$, where $\mathrm{RF}$ means research flight). These ratios were comparable to those obtained from controlled laboratory burns and suggested that the emissions sampled during RF01/F02/RF03/RF05 were dominated by the burning of grasses, RF08 by leaves, RF09A by needles, and RF09B by marsh grasses. These findings were further supported by the $\Delta$ galactosan / $\Delta$ levoglucosan ratios $\left(\mathrm{RF} 01 / \mathrm{RF} 02 / \mathrm{RF} 03 / \mathrm{RF} 05=0.067 \pm 0.004 \mu \mathrm{g} \mu \mathrm{g}^{-1}, \mathrm{RF} 08\right.$ $=0.085 \pm 0.009 \mu \mathrm{g} \mathrm{g}^{-1}$, and RF09A $=0.101 \pm 0.029$ $\mu \mathrm{g} \mu \mathrm{g}^{-1}$ ) obtained as well as by the ground-based fuel and filter sample analyses during RF01/RF02/RF03/RF05. Differences between $\Delta$ potassium / $\Delta$ levoglucosan ratios obtained for these prescribed fires vs. laboratory-scale measurements suggest that some laboratory burns may not accurately represent potassium emissions from prescribed burns. The $\Delta$ levoglucosan / $\Delta$ WSOC ratio had no clear dependence
\end{abstract}

on smoke age or fire dynamics suggesting that this ratio is more dependent on the type of fuel being burned. Levoglucosan was stable over a timescale of at least $1.5 \mathrm{~h}$ and could be useful to help estimate the air quality impacts of biomass burning.

\section{Introduction}

The smoke marker approach is the most common method used to estimate the contribution of primary biomass burning to the total organic carbon aerosol concentration (e.g., Schauer et al., 1996; Schauer and Cass, 2000; Fraser et al., 2003; Rinehart et al., 2006). In this approach, a compound produced as part of the smoke (i.e., smoke marker) is monitored as a plume is transported downwind. If the smoke marker is conserved, or decays at a known rate, during transport and the ratio of the smoke marker to the total organic carbon is known at the source, then a downwind measurement of the smoke marker's concentration can be used to apportion the contribution of primary biomass burning emissions to the total organic carbon.

Generally, source sample smoke marker ratios are obtained from ground-based studies utilizing integrated filter sampling with sample collection over the duration of the entire fire (e.g., Hays et al., 2002; Fine et al., 2004; Lee et al., 2005; Mazzoleni et al., 2007). One of the main reasons for this approach is that traditional methods used to measure smoke markers, such as gas chromatography-mass spectrometry (GC-MS), generally require a high concentration of 
a particular organic species for analysis. In order to reach this concentration a large amount of aerosol mass must be collected. Therefore, ground-based sampling would provide the best means to collect a large amount of aerosol mass as this is generally not feasible from an aircraft platform that can quickly fly through a plume.

However, being able to measure smoke marker concentrations from an aircraft platform could be useful. Sampling a smoke plume right after emission as well as following it downwind during transport could help to better characterize source smoke marker ratios and any evolution due to plume dilution and aging. In addition, collecting multiple samples from the same fire, which is often not feasible with filter sampling due to the time required to collect sufficient mass, would be possible.

As a first attempt to make airborne smoke marker measurements, a PILS-TOC (Particle-Into-Liquid Sampler - Total Organic Carbon) and fraction collector system was flown aboard a Twin Otter aircraft in November 2011 as it sampled emissions from prescribed burning activities taking place in South Carolina. This study was the last field deployment in a series of measurements of prescribed burning emissions from the southeastern US (Burling et al., 2010, 2011; Akagi et al., 2013; Yokelson et al., 2013). The idea behind the chosen instrumentation was to provide a $3 \mathrm{~s}$ time-integrated measurement of water-soluble organic carbon (WSOC), whose two main sources are biomass burning and secondary organic aerosol (SOA), from the PILS-TOC (Sullivan et al., 2004, 2006), then take advantage of the high sensitivity and low limit of detection of high-performance anion-exchange chromatography with pulsed amperometric detection (HPAECPAD) to analyze the fraction collector samples offline to provide a near-real-time measurement of carbohydrates (i.e., smoke markers). PAD is an electrochemical technique where hydroxyl groups are electroanalytically oxidized on the surface of a gold electrode. This approach offers numerous advantages including extraction of an aerosol sample directly in water (i.e., no derivatization or organic solvents are needed) and the ability to directly analyze an aqueous sample for smoke markers. This technique has been applied to biomass burning source samples as well as studies examining ambient aerosol contributions by biomass burning (Gao et al., 2003; Gorin et al., 2006; Engling et al., 2006; Puxbaum et al., 2007; Sullivan et al., 2008, 2011a, b).

In this work, measurements of WSOC and various smoke markers - including levoglucosan, mannosan, galactosan, and water-soluble potassium - for five different prescribed burns (six research flights) are presented. Smoke marker ratios for the various prescribed burns are discussed and compared with results from biomass burning source samples collected from controlled laboratory burns and on the ground. The influence of plume aging and fire dynamics on smoke marker ratios is also investigated.

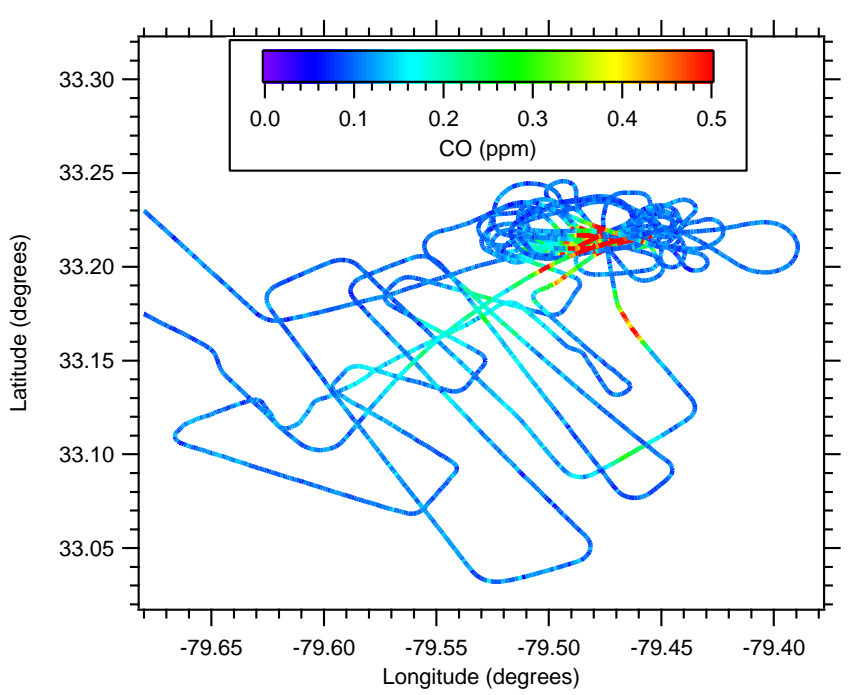

Figure 1. Example of a typical flight path. This flight path is from RF08 and is colored by CO to indicate the location of the burn and where the smoke plume was intercepted downwind.

\section{Methods}

\subsection{Airborne mission}

The research flights conducted were part of a combined ground-based and airborne-based study to examine the emissions from prescribed burning in the southeastern US. In the southeastern US, prescribed burning is often implemented every 1-4 years in wildlands to maintain or restore fireadapted ecosystems. Burns are conducted so fuel consumption will only be in the understory and the forecast transport is such that smoke impacts will be minimal. Therefore, in general, prescribed burns are less intense than wildfires.

The Twin Otter used in our study was operated out of Columbia, SC (South Carolina), from 29 October 2011 to 11 November 2011. Measurements were made of several chemical and physical aerosol particle properties, and of reactive and stable trace gases. Table 1 provides a list of the flights when the PILS-TOC and fraction collector sampler operated. The first flights (RF01/RF02/RF03/RF05, where RF means research flight) focused on prescribed burning at Fort Jackson, SC. Once these burns were completed, airborne sampling only of other prescribed burns taking place in SC began (RF08 and RF09). A typical flight involved first characterizing the emissions right at the source with numerous passes through the smoke (Fig. 1). Then the smoke was sampled downwind mostly by crossing back and forth through the plume further and further downwind until it could not be distinguished from the background air. On flights RF03, RF08, and RF09, sampling of the smoke downwind was achieved. 


\subsection{Particle collection}

A PILS was used to collect ambient particles into purified water, providing the liquid sample for analysis (Orsini et al., 2003). Upstream of the PILS were two honeycomb denuders coated with sodium carbonate and phosphoric acid to remove inorganic gases and an activated carbon parallel plate denuder (Eatough et al., 1993) to remove organic gases. In addition, a normally open actuated valve controlled by an external timer was periodically closed every $2 \mathrm{~h}$ for $10 \mathrm{~min}$ forcing the airflow through a Teflon filter before entering the PILS, allowing for determination of the particle-free background. Ambient concentrations were then calculated as the difference between the nonfiltered and filtered (particle-free background) measurements. For the real-time WSOC concentrations the particle-free background was assumed to be constant between consecutive particle-free background measurements, and the average particle-free background measurement following a set of nonfiltered measurements was applied.

The PILS setup was generally similar to that of Sullivan et al. (2006) with some modifications to the liquid flow rates to allow for one PILS to be used for all measurements. The liquid flow rate over the impactor, controlled by two Kloehn syringe pumps with $2.5 \mathrm{~mL}$ syringes, was increased to $2 \mathrm{~mL} \mathrm{~min}^{-1}$. The liquid sample obtained from the PILS was pushed through a $0.5 \mu \mathrm{m}$ PEEK (polyetheretherketone) liquid filter, by a second set of syringe pumps at a flow rate of $1.8 \mathrm{~mL} \mathrm{~min}^{-1}$, to ensure any insoluble particles were removed. The flow was then split between the TOC analyzer and fraction collector.

The TOC analyzer used was a Sievers Model 800 Turbo TOC Analyzer. This instrument converts the organic carbon in a liquid sample to carbon dioxide through chemical oxidation involving ultraviolet light and ammonium persulfate and quantifies the conductivity of the produced carbon dioxide. The amount of organic carbon in the sample is proportional to this measured increase in conductivity. The analyzer was run in Turbo mode providing a $3 \mathrm{~s}$ time-integrated measurement of WSOC with a limit of detection (LOD) of $0.1 \mu \mathrm{g} \mathrm{C} \mathrm{m}^{-3}$.

A Foxy 200 Fraction Collector (Teledyne ISCO) was used to collect the samples for offline analysis. It can hold up to two hundred $16 \mathrm{~mL}$ uncapped polystyrene test tubes (Becton Dickinson Labware). Test tubes were used as supplied by the manufacturer and required no precleaning before use. The fraction collector program, which was manually started at takeoff, was set to allow for continuous collection of $2 \mathrm{~min}$ time-integrated samples. Based on the liquid flow rates used for the PILS, each test tube collected approximately $1.6 \mathrm{~mL}$ of sample. At the completion of each flight, the test tubes were capped, packed in coolers with ice packs, and shipped back to Colorado State University to be stored in a $2{ }^{\circ} \mathrm{C}$ cold room until analysis.

\subsection{Offline analysis}

Each fraction collector test tube was brought back to room temperature before analysis. Two $600 \mu \mathrm{L}$ aliquots were transferred to separate polypropylene vials for carbohydrate and cation measurements.

The carbohydrate analysis was performed on a Dionex DX-500 series ion chromatograph with an ED-50 electrochemical detector operating in integrating amperometric mode using waveform A and a GP-50 gradient pump. The detector contains an ED-50/ED-50A electrochemical cell. This cell includes a $\mathrm{pH}-\mathrm{Ag} / \mathrm{AgCl}$ (silver/silver chloride) reference electrode and "standard" gold working electrode. The separation was performed using a Dionex CarboPac PA-1 column $(4 \times 250 \mathrm{~mm})$ employing a sodium hydroxide gradient. The complete run time was $59 \mathrm{~min}$ and an injection volume of $50 \mu \mathrm{L}$ was used. More details of the method can be found in Sullivan et al. (2011a, b). Of the carbohydrates that can be detected by this method, levoglucosan, mannosan, and galactosan were found in all samples. Glucose and arabinose were only occasionally detected and will not be discussed further. The LOD for the various carbohydrates was calculated to be less than approximately $0.10 \mathrm{ng} \mathrm{m}^{-3}$.

Water-soluble potassium was measured using a second Dionex DX-500 ion chromatograph. This system included an isocratic pump, self-regenerating cation SRS-ULTRA suppressor, and conductivity detector. A Dionex IonPac CS12A analytical column $(3 \times 150 \mathrm{~mm})$ using $20 \mathrm{mM}$ methanesulfonic acid at a flow rate of $0.5 \mathrm{~mL} \mathrm{~min}^{-1}$ was used for the separation. The injection volume and analysis time were $50 \mu \mathrm{L}$ and $17 \mathrm{~min}$, respectively. Unlike for the carbohydrates, a blank correction was necessary for the water-soluble potassium. Concentrations were corrected by using the average of all particle-free background samples (i.e., with the actuated valve before the PILS in the closed position) collected during a specific flight. The LOD for water-soluble potassium was $0.02 \mu \mathrm{g} \mathrm{m}^{-3}$.

\subsection{Other measurements}

In the analysis presented in this paper we focus on characterizing source smoke marker ratios from prescribed burning. Other measurements presented here include 3-D location and wind speed collected with a wing-mounted Aircraft Integrated Meteorological Measuring System probe (AIMMS20, Aventech Research, Inc.) to estimate time since emission values, $6 \mathrm{~s}$ time-integrated organic aerosol (OA) concentrations determined by a high-resolution - time-of-flight - aerosol mass spectrometer (HR-ToF-AMS) (DeCarlo et al., 2006), $1 \mathrm{~Hz}$ carbon monoxide (CO) determined by a $\mathrm{Pi}-$ carro cavity ring-down spectrometer, and AFTIR (airborne Fourier transform infrared spectrometer) data analysis products including modified combustion efficiency (MCE) ratios (Yokelson et al., 1999; Burling et al., 2011; Akagi et al., 2013). 
Table 1. Information for each research flight with the PILS-TOC and fraction collector system including flight number, date and sampling time (local time, LT) as well as the location and size of the fire being sampled.

\begin{tabular}{lllll}
\hline $\begin{array}{l}\text { Flight } \\
\text { number* }\end{array}$ & $\begin{array}{l}\text { Date and time } \\
\text { (LT) }\end{array}$ & Fire location & $\begin{array}{l}\text { Coordinates } \\
\text { (degrees) }\end{array}$ & $\begin{array}{l}\text { Acres } \\
\text { burned } \\
\text { (ha) }\end{array}$ \\
\hline RF01 & 30 Oct 11 & Fort Jackson, & $34^{\circ} 1^{\prime} 29^{\prime \prime}$, & 61.9 \\
& $12: 30-14: 00$ & SC Block 6 & $80^{\circ} 52^{\prime} 16^{\prime \prime}$ & \\
RF02 & 30 Oct 11 & Fort Jackson, & $34^{\circ} 1^{\prime} 29^{\prime \prime}$, & 61.9 \\
& $15: 00-17: 10$ & SC Block 6 & $80^{\circ} 52^{\prime} 16^{\prime \prime}$ & \\
RF03 & 1 Nov 11 & Fort Jackson, & $34^{\circ} 0^{\prime} 15^{\prime \prime}$, & 36.0 \\
& $12: 00-15: 00$ & SC Block 9b & $80^{\circ} 52^{\prime} 37^{\prime \prime}$ & \\
RF05 & 2 Nov 11 & Fort Jackson, & $34^{\circ} 5^{\prime} 4^{\prime \prime}$, & 28.7 \\
& $13: 00-17: 00$ & SC Block 22b & $80^{\circ} 46^{\prime} 23^{\prime \prime}$ & \\
RF08 & 8 Nov 11 & Francis Marion & $33^{\circ} 12^{\prime} 55^{\prime \prime}$, & 147 \\
& $12: 00-16: 00$ & National Forest, SC & $79^{\circ} 28^{\prime} 34^{\prime \prime}$ & \\
RF09 & 10 Nov 11 & Midway, & $33^{\circ} 14^{\prime} 5^{\prime \prime}$, & 36.4 \\
& $11: 00-13: 00$ & SC Bamberg Burn & $80^{\circ} 56^{\prime} 41^{\prime \prime}$ & \\
\hline
\end{tabular}

${ }^{*}$ RF means research flight. For RF04 the PILS system was not operational. RF06 was a flight over Columbia to examine urban emissions and did not sample any burning. RF07 had limited access to a prescribed burn in Georgetown, SC, due to it being conducted on private land, leading to few smoke-impacted fraction collector samples. RF09 is denoted as RF09A and RF09B throughout to indicate the two different ends of this burn.

All aircraft aerosol instruments were sampled from a LTI (low turbulence inlet) (Wilson et al., 2004). Following the LTI was a nonrotating MOUDI impactor with a $50 \%$ transmission efficiency at $1 \mu \mathrm{m}$ and $1 \mathrm{~atm}$ ambient pressure (Marple et al., 1991). The combined flow through the inlet and MOUDI was approximately $20 \mathrm{~L} \mathrm{~min}^{-1}$ and was then split to the individual instruments.

\section{Results and discussion}

\subsection{Overview}

In Fig. 2, using flight RF01 as an example, a time series for $1 \mathrm{~s}$ absolute CO, levoglucosan, and WSOC is shown. Altitude is also included to illustrate the typical profile flown. $\mathrm{CO}$, WSOC, and levoglucosan concentrations rise and fall together as the aircraft flies in and out of the smoke plume. In order to take a closer look at the levoglucosan data, the WSOC concentrations can be averaged to match the fraction collector times. It can be seen that the $2 \mathrm{~min}$ resolution of the fraction collector does capture the plume penetrations (Fig. 3a). In addition, the ratio between levoglucosan and WSOC appears to be fairly constant $\left(R^{2}=0.93\right.$ for all data), which will be discussed in more detail in the next section. A times series for the absolute concentrations for all three anhydrosugars measured from the fraction collector samples can be seen in Fig. $3 \mathrm{~b}$ for this same flight (RF01). As is typically observed, levoglucosan dominated followed by mannosan then galactosan. All three species concentrations tracked each other and were highly correlated $\left(R^{2}>0.90\right)$.

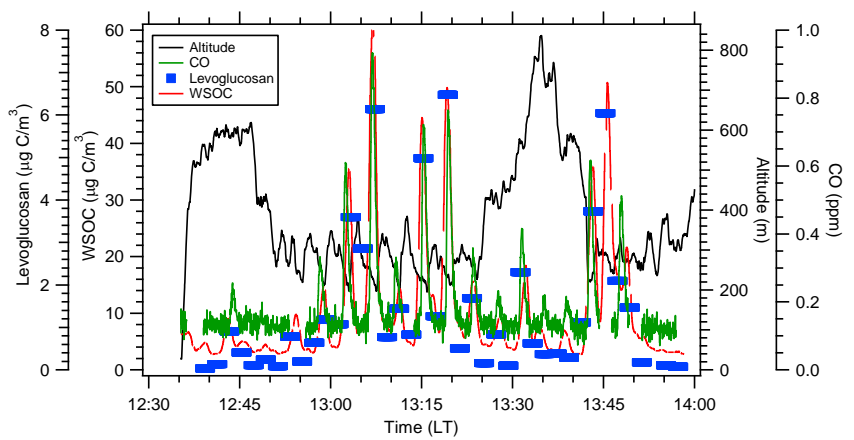

Figure 2. Time series of $1 \mathrm{~s}$ altitude along with absolute $\mathrm{CO}$, levoglucosan, and WSOC from RF01.

\subsection{Smoke marker ratios}

In order to investigate smoke marker ratios, we considered only fraction collector samples collected in the smoke plume. Given the longer integration time for the fraction collector system, the fraction collector data set was filtered using the CO data. Only fraction collector samples that directly overlapped with a CO plume penetration are considered. Given the longer response time constant of the PILS (due to being a liquid system; Sorooshian et al., 2006) vs. the other instruments, we initially focus on internal comparisons of species concentrations measured by the PILS. The absolute WSOC, levoglucosan, mannosan, galactosan, and potassium concentrations along with altitude data for this subset of data from all flights is given in Supplement Table S1. Throughout for all flights excess ratios (denoted by $\Delta$ ) will be presented and were determined as the difference in the concentration when in and outside of a smoke plume. The concentrations of WSOC, levoglucosan, mannosan, galactosan, and potassium used for all flights outside of a smoke plume were $2.00 \mu \mathrm{g} \mathrm{C} \mathrm{m}^{-3}, 0.03 \mu \mathrm{g} \mathrm{m}^{-3}, 0.03 \mu \mathrm{g} \mathrm{m}^{-3}, 0.03 \mu \mathrm{g} \mathrm{m}^{-3}$, and $0.30 \mu \mathrm{g} \mathrm{m}^{-3}$, respectively.

The correlation of $\Delta$ levoglucosan with $\triangle \mathrm{WSOC}$ is shown in Fig. 4a. All the burns occurring at Fort Jackson (RF01/RF02/RF03/RF05) appeared to have a similar ratio, based on the slope of the linear correlation, of $0.163 \pm 0.007 \mu \mathrm{g} \mathrm{C}_{\mu \mathrm{g}}{ }^{-1} \mathrm{C}$. In addition, there appeared to be no concentration dependence or significant altitude dependence on this ratio (Fig. 4b). The smoke sampled during RF08 had lower $\Delta$ levoglucosan $/ \triangle \mathrm{WSOC}$ ratios (approximately $0.115 \pm 0.011 \mu \mathrm{g} \mathrm{C} \mu \mathrm{g}^{-1} \mathrm{C}$ ) than the ratios for the Fort Jackson burns. Interestingly, the fire sampled during RF09 appeared to have two distinct groups of $\Delta$ levoglucosan $/ \triangle \mathrm{WSOC}$ ratios (denoted RF09A and RF09B). Group B had only a few samples, so linear regression statistics were not reliable. Therefore, throughout the average ratio \pm standard deviation was calculated for RF09B. The $\Delta$ levoglucosan $/ \triangle$ WSOC ratio was $0.042 \pm 0.008 \mu \mathrm{g} \mathrm{C}_{\mu \mathrm{g}}{ }^{-1} \mathrm{C}$ for RF09B, which was lower

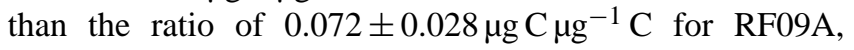


Table 2. WSOC to OC, levoglucosan to WSOC on a carbon mass basis, galactosan to levoglucosan, mannosan to levoglucosan, and potassium to levoglucosan ratios from controlled laboratory burns. Ratios were determined as the slope of a linear regression between the two species using data from the Fire Lab at Missoula Experiments (FLAME) (Sullivan et al., 2014).

\begin{tabular}{|c|c|c|c|c|c|}
\hline Fuel type & $\begin{array}{c}\text { WSOC / OC } \\
\left(\mu g \mathrm{C}^{-1} \mathrm{C}\right)\end{array}$ & $\begin{array}{c}\text { Levoglucosan / } \\
\text { WSOC } \\
\left(\mu \mathrm{gC} \mu \mathrm{g}^{-1} \mathrm{C}\right)\end{array}$ & $\begin{array}{c}\text { Galactosan / } \\
\text { levoglucosan } \\
\left(\mu g \mu g^{-1}\right)\end{array}$ & $\begin{array}{c}\text { Mannosan / } \\
\text { levoglucosan } \\
\left(\mu g \mu g^{-1}\right)\end{array}$ & $\begin{array}{l}\text { Potassium / } \\
\text { levoglucosan } \\
\left(\mu \mathrm{g} \mu \mathrm{g}^{-1}\right)\end{array}$ \\
\hline Grasses & $0.81 \pm 0.02$ & $0.149 \pm 0.012$ & $0.060 \pm 0.005$ & $0.051 \pm 0.005$ & $0.211 \pm 0.026$ \\
\hline Leaves* & $0.54 \pm 0.02$ & $0.095 \pm 0.006$ & $0.094 \pm 0.009$ & $0.027 \pm 0.008$ & no correlation \\
\hline Needles* & $0.54 \pm 0.02$ & $0.064 \pm 0.008$ & $0.119 \pm 0.010$ & $0.249 \pm 0.016$ & $0.079 \pm 0.009$ \\
\hline Marsh grasses & $0.78 \pm 0.07$ & $0.017 \pm 0.014$ & $0.095 \pm 0.038$ & $0.006 \pm 0.002$ & no correlation \\
\hline
\end{tabular}

* Includes the burning of live and dead material.
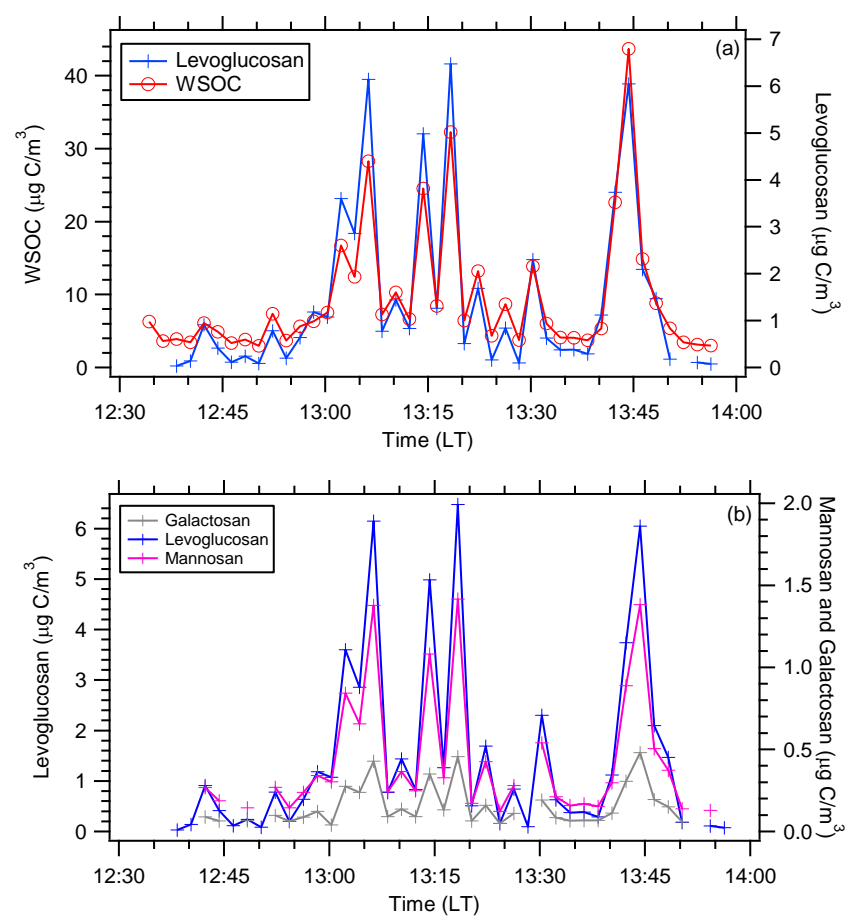

Figure 3. Times series of 2 min absolute (a) levoglucosan and WSOC and (b) galactosan, levoglucosan, and mannosan from RF01.

suggesting that the vegetation may have been different at the two ends of the fire being sampled during RF09. In South Carolina it is very common for marshy bays to be mixed in with a forested area (B. Manks, personal communication, 2011). In addition, an independent analysis to calculate the emission ratios for these same fires found two groups of emission ratios for the fire sampled during RF09 (May et al., 2014b).

The importance of the fuel type combusted can be further illustrated by comparing the airborne smoke marker ratios to those from typical biomass burning source samples collected from controlled laboratory burns $(0.149 \pm$ $0.012 \mu \mathrm{g} \mathrm{C} \mu \mathrm{g}^{-1} \mathrm{C}$ for grasses, $0.095 \pm 0.006 \mu \mathrm{g} \mathrm{C} \mu \mathrm{g}^{-1} \mathrm{C}$

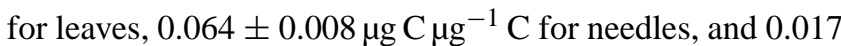
$\pm 0.014 \mu \mathrm{g} \mathrm{C} \mu \mathrm{g}^{-1} \mathrm{C}$ for marsh grasses; Table 2). Similarities in smoke marker ratio values suggest that the Fort Jackson burns (RF01/RF02/RF03/RF05) were dominated by the burning of grasses, RF08 by leaves, RF09A by needles, and RF09B by marsh grasses. Ground-based sampling of the Fort Jackson burns included fuel characterization (Yokelson et al., 2013), which indicated the interior environment was a longleaf pine/wiregrass system. One HiVolume quartz filter sample was collected across each burn at the Fort Jackson ground-based sampling site. Analysis of the filters provided an average levoglucosan / WSOC ratio of $0.198 \pm 0.001 \mu \mathrm{g} \mathrm{C} \mu \mathrm{g}^{-1} \mathrm{C}$, which is on the higher end of the range of ratios observed for RF01/RF02/RF03/RF05 (Fig. 4a).

The ratio of $\Delta$ galactosan to $\Delta$ levoglucosan, like the $\Delta$ levoglucosan to $\triangle$ WSOC ratio, varied between fires $\left(\mathrm{RF} 01 / \mathrm{RF} 02 / \mathrm{RF} 03 / \mathrm{RF} 05=0.067 \pm 0.004 \mu \mathrm{g}^{-1}, \mathrm{RF} 08\right.$ $=0.085 \pm 0.009 \mu \mathrm{g}^{-1}$, and RF09A $=0.101 \pm 0.029$ $\mu \mathrm{g} \mu \mathrm{g}^{-1}$; Fig. 5a). This ratio from controlled laboratory burns also varied across fuel types $\left(0.060 \pm 0.005 \mu \mathrm{g} \mu \mathrm{g}^{-1}\right.$

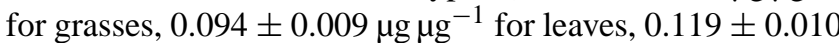
$\mu \mathrm{g} \mathrm{g}^{-1}$ for needles, and $0.095 \pm 0.038 \mu \mathrm{g} \mu \mathrm{g}^{-1}$ for marsh grasses; Table 2). As with the $\Delta$ levoglucosan / $\Delta$ WSOC ratios, similarities between research flight and lab burn ratios of $\Delta$ galactosan / $\Delta$ levoglucosan suggest RF01/RF02/RF03/RF05 emissions were likely dominated by combustion of grasses, RF08 sampled emissions from combustion of leaves, and RF09A was impacted by needle burning.

However, the $\Delta$ mannosan to $\Delta$ levoglucosan ratios observed in the research flights do not compare as well to ratios measured in controlled laboratory burns. The controlled laboratory burn ratio for grasses of $0.051 \pm 0.005 \mu \mathrm{g} \mathrm{\mu \textrm {g } ^ { - 1 }}$ is much lower than the ratio for RF01/RF02/RF03/RF05 of $0.207 \pm 0.004 \mu \mathrm{g} \mathrm{gg}^{-1}$. The controlled laboratory burn ratio for leaves of $0.027 \pm 0.008 \mu \mathrm{g} \mathrm{g}^{-1}$ is also much lower than the ratio for RF08 $\left(0.174 \pm 0.008 \mu \mathrm{g} \mathrm{g}^{-1}\right)$. In contrast, the $\Delta$ mannosan/ $\Delta$ levoglucosan ratio for RF09A 

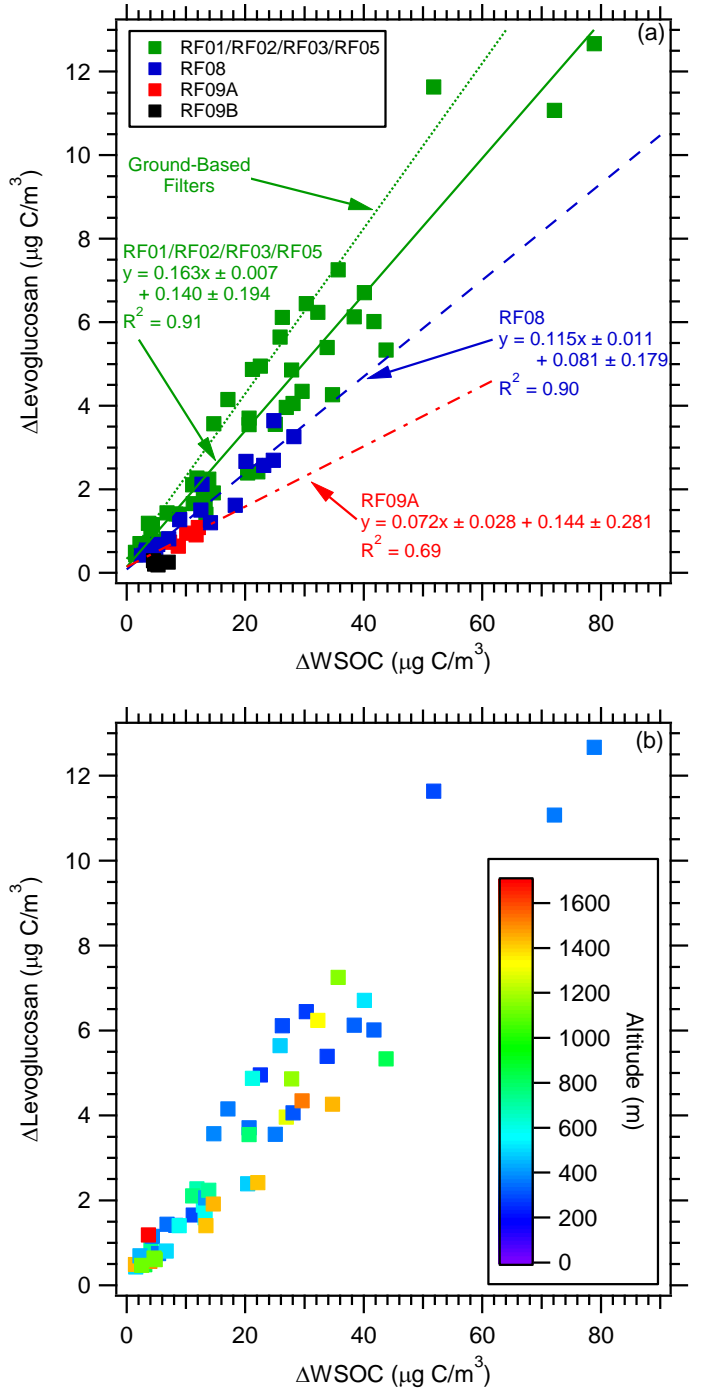

Figure 4. Correlation of (a) $\Delta$ levoglucosan vs. $\triangle \mathrm{WSOC}$ on a carbon mass basis for all flights with the data segregated by fire location and (b) $\Delta$ levoglucosan vs. $\triangle \mathrm{WSOC}$ on a carbon mass basis for only the Fort Jackson prescribed burns colored by altitude. In plot (a), the fit through the filter samples collected on the ground during the burns conducted at Fort Jackson is also provided. Uncertainties with the least-square regressions are one standard deviation.

$\left(0.169 \pm 0.102 \mu \mathrm{g} \mu \mathrm{g}^{-1}\right)$ is less than the controlled laboratory burn ratio for needles $\left(0.249 \pm 0.016 \mu \mathrm{g} \mu \mathrm{g}^{-1}\right)$.

Water-soluble potassium has long been used as an inorganic marker for biomass burning. As can be seen in Fig. $5 \mathrm{c}$, the prescribed burn observations contain quite a bit of scatter in the $\Delta$ potassium to $\Delta$ levoglucosan ratio, even for a particular burn location. For example, attempting a linear fit to the data from the burns at Fort Jackson (RF01/RF02/RF03/RF05) yields a very low $R^{2}$ value of 0.13 ; although there is somewhat of a better correlation for RF08 $\left(R^{2}=0.41\right)$. Poor correlation between potassium and levoglucosan concentrations in biomass burning smoke is not
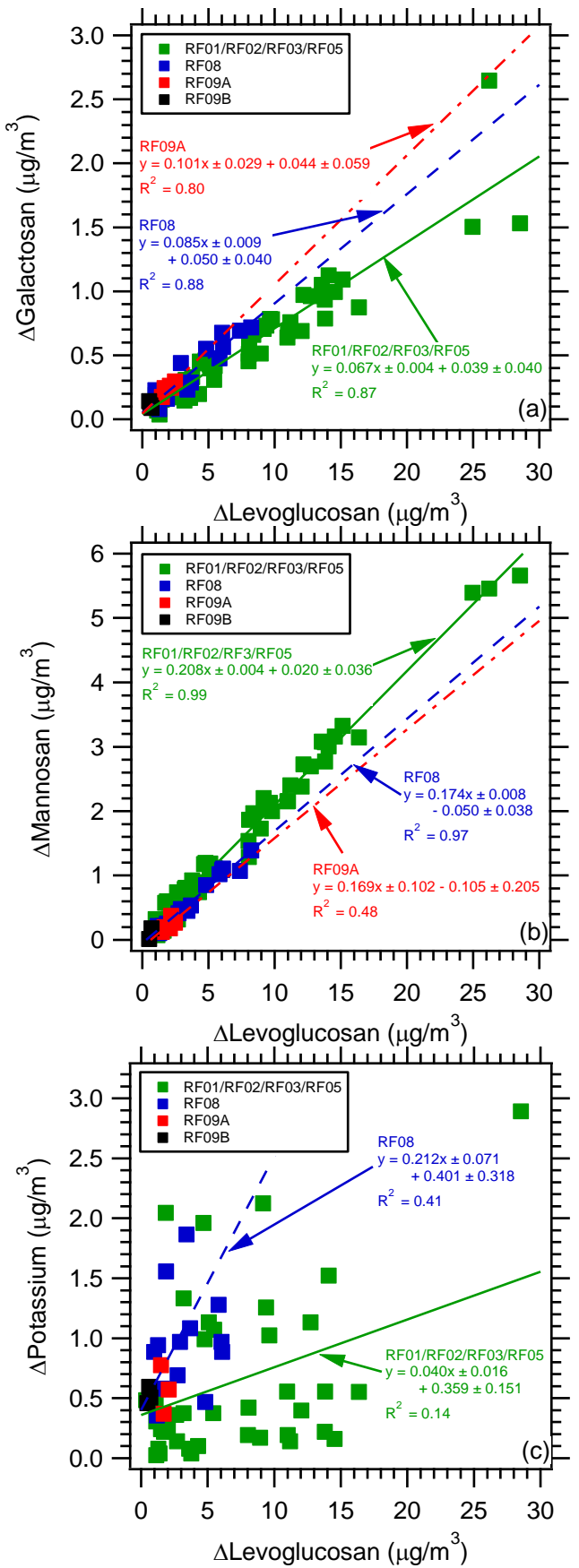

Figure 5. Correlation of (a) $\Delta$ galactosan vs. $\Delta$ levoglucosan, (b) $\Delta$ mannosan vs. $\Delta$ levoglucosan, and (c) $\Delta$ potassium vs. $\Delta$ levoglucosan for all flights with the data segregated by fire location. Uncertainties with the least-square regressions are one standard deviation.

surprising. The presence of a small amount of inorganic substances, such as potassium, in a fuel can cause changes in the product yields of levoglucosan during cellulose pyrolysis, with potassium suppressing the formation of levoglucosan (Radlein et al., 1991; Richards et al., 1991; Patwardhan et 

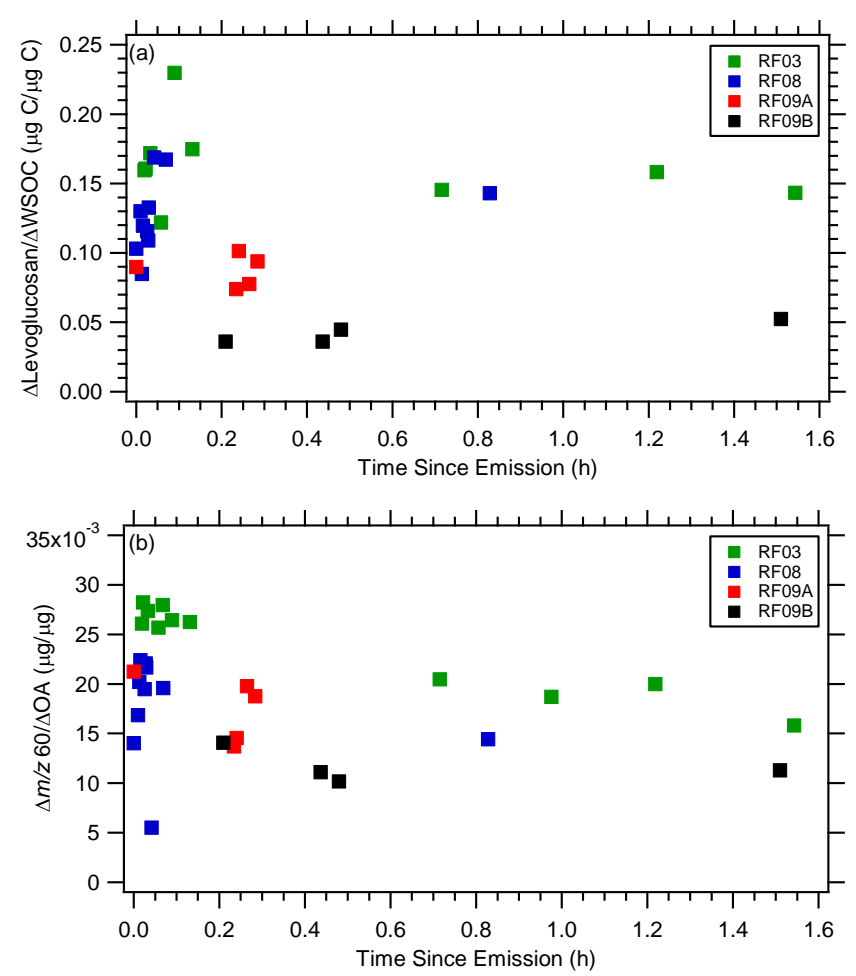

Figure 6. (a) $\Delta$ Levoglucosan $/ \Delta$ WSOC ratio on a carbon mass basis and (b) $\Delta m / z 60 / \Delta \mathrm{OA}$ ratio as a function of time since emission for all flights with the data segregated by fire location.

al., 2010; Eom et al., 2012). In addition, potassium is predominately emitted from the flaming phase of a fire, whereas levoglucosan is emitted across both smoldering and flaming fire phases (Ward et al., 1991; Echalar et al., 1995; Lee et al., 2010). Changes in the mix of flaming and smoldering combustion in a laboratory or prescribed burn, therefore, can readily yield large differences in the emitted abundances of potassium.

\subsection{Role of aging and fire dynamics}

The time since emission (i.e., the smoke age) was estimated for all possible downwind aircraft smoke marker samples from RF03, RF08, RF09A, and RF09B as the distance from the source divided by the average wind speed for the sampling altitude (Akagi et al., 2013). Pseudo-Lagrangian sampling was accomplished for the majority of these downwind samples, meaning the aircraft was sampling the source of the fires at their estimated time of emission (see Akagi et al., 2013, for more details). Changes in plume composition occur with plume aging, due both to plume dilution (which can influence gas-to-particle partitioning) and photochemical reactions, but very little data quantitatively examines the impact (if any) of these processes on smoke marker ratios. Since a smoke marker ratio is needed to apportion the contribution of biomass burning, this is important to investigate. But it is

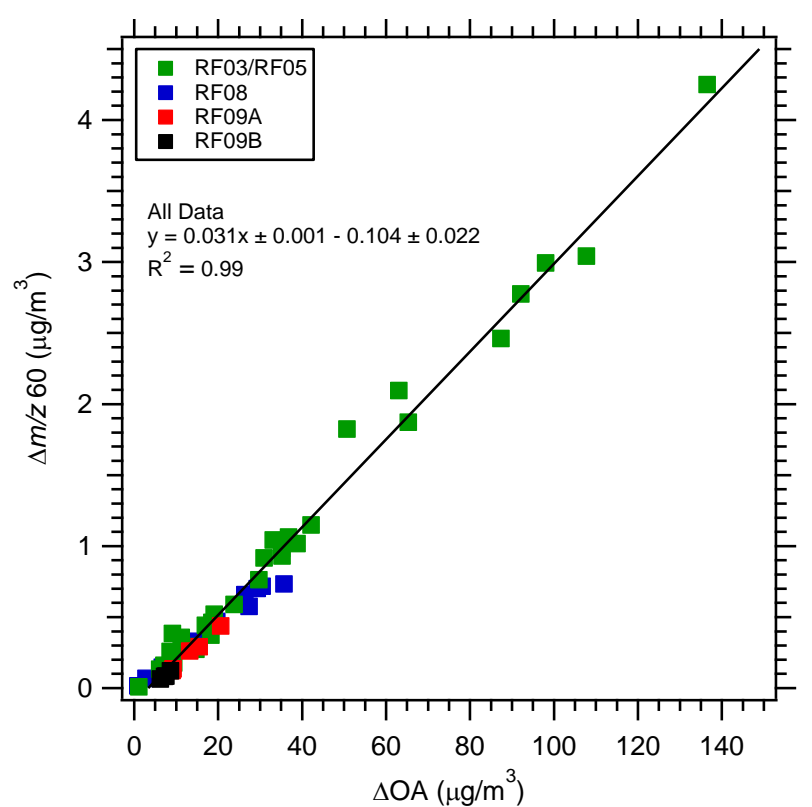

Figure 7. Correlation of $\Delta m / z 60$ vs. $\Delta \mathrm{OA}$ for all flights with the data segregated by fire location. Uncertainty with the least-square regression is one standard deviation.

also important to note this impact would depend on the rates of reaction of levoglucosan and WSOC, which are unknown and could be similar.

Figure 6a shows the $\Delta$ levoglucosan / $\Delta$ WSOC ratio as a function of time since emission. Over the range of smoke plume ages (up to approximately $1.5 \mathrm{~h}$ ), the observations give no clear indication that the ratio changes across a fuel type or fire location in a consistent manner as the plume ages. Low ratios in RF09B, for example, remain low, while higher initial ratios in RF03 remain high. These observations suggest that the $\Delta$ levoglucosan $/ \Delta$ WSOC source smoke marker ratio is stable for at least $1-1.5 \mathrm{~h}$ as the plume dilutes and ages.

We can also make use of a subset of observations from the AMS to look at plume characteristics for the different flights. Of particular interest from a source apportionment perspective is the ratio of the key AMS biomass burning marker at $\mathrm{m} / \mathrm{z} 60$ to AMS total OA. Figure 7 plots $\Delta m / z 60$ vs. $\Delta \mathrm{OA}$ concentrations for flights RF03, RF05, RF08, and RF09. (Concentrations used for all flights for OA and $m / z 60$ outside of a smoke plume were 4.00 and $0.003 \mu \mathrm{g} \mathrm{m}^{-3}$, respectively.) Despite the differences in fuel type and $\Delta$ levoglucosan / $\triangle$ WSOC ratios across burns described above, this AMS ratio shows a very tight relationship $\left(R^{2}=0.99\right.$ for RF03/RF05, $R^{2}=0.98$ for RF08, $R^{2}=0.99$ for RF09A, and $R^{2}=0.99$ for all data). A $\Delta$ OA concentration of $3.35 \mu \mathrm{g} \mathrm{m}^{-3}$ associated with no $\mathrm{m} / \mathrm{z} 60$ suggests a background OA concentration from other sources onto which the smoke aerosol is added. There is some change apparent in this ratio as a function of plume age (Fig. 6b). A bigger spread of ratios across fresh, individual plumes appears 

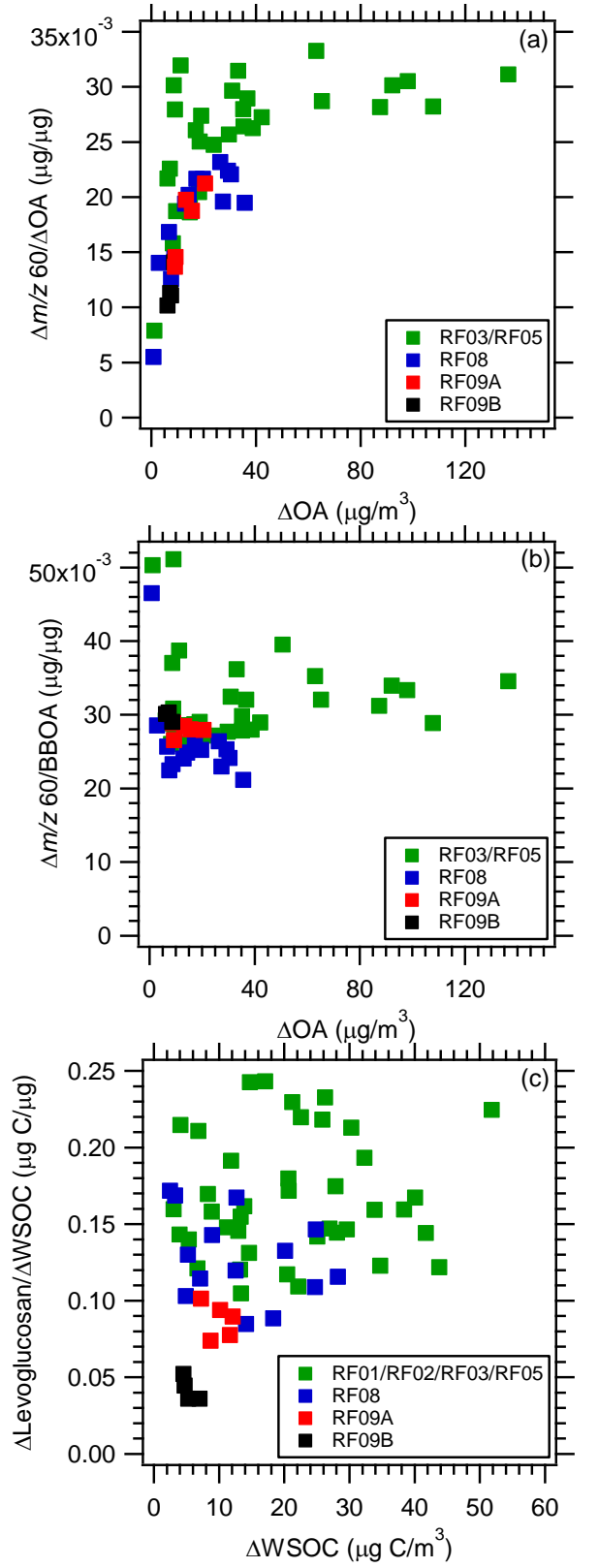

Figure 8. (a) $\Delta m / z 60 / \Delta \mathrm{OA}$ ratio as a function of $\Delta \mathrm{OA}$, (b) $\Delta m / z 60 / \mathrm{BBOA}$ ratio as a function of $\Delta \mathrm{OA}$, and (c) $\Delta$ levoglucosan / $\triangle$ WSOC ratio on a carbon mass basis as a function of $\triangle$ WSOC for all flights with the data segregated by fire location.

to rapidly converge to a more consistent ratio in less than approximately $0.5 \mathrm{~h}$ of plume aging. Although $m / z 60$ is often identified with levoglucosan, it can be comprised of a variety of structurally similar molecules (Aiken et al., 2009; Mohr et al., 2009; Lee et al., 2010). While differences in levoglucosan emissions across fuel type are apparent from the PILS measurements discussed above, emissions of the larger suite of structurally similar molecules that fragment to yield $\mathrm{m} / \mathrm{z} 60$ appear to be more constant across fuel types.
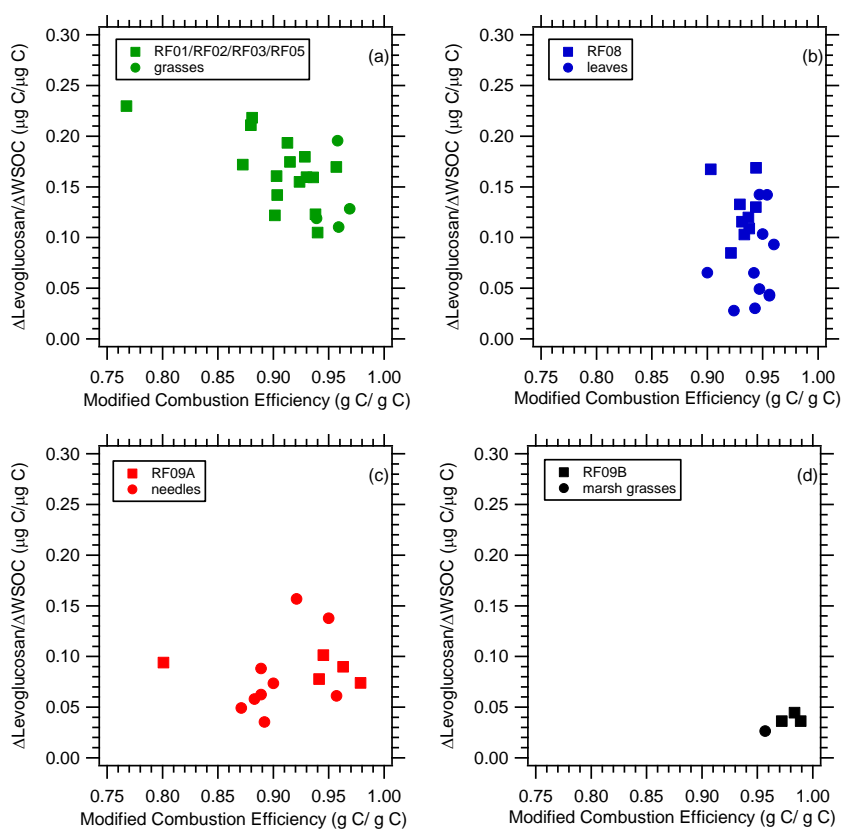

Figure 9. $\Delta$ Levoglucosan/ $\Delta \mathrm{WSOC}$ ratio on a carbon mass basis for (a) RF01/RF02/RF03/RF05 and controlled laboratory burns involving grasses, (b) RF08 and controlled laboratory burns involving leaves, (c) RF09A and controlled laboratory burns involving needles, and (d) RF09B and controlled laboratory burns involving marsh grasses as a function of modified combustion efficiency. In each plot the squares represent the prescribed burns and circles controlled laboratory burns.

The $\Delta m / z 60 / \Delta \mathrm{OA}$ concentration ratio is plotted as a function of the $\triangle \mathrm{OA}$ concentration in Fig. 8a. Below $\triangle \mathrm{OA}$ concentrations of approximately $50 \mathrm{\mu g} \mathrm{m}^{-3}$, the ratio is strongly related to the $\triangle \mathrm{OA}$ concentration. At higher concentrations, the ratio levels off. If a simple two-factor positive matrix factorization (PMF) solution is applied to this AMS OA data, it can provide background OA and biomass burning OA (BBOA) concentrations (May et al., 2014a). If we then plot the ratio of $\Delta m / z 60 / \mathrm{BBOA}$ as a function of total $\triangle \mathrm{OA}$ (Fig. 8b), we observe much less concentration dependence. This suggests that changes in the $\Delta m / z 60 / \Delta \mathrm{OA}$ ratio as a function of $\triangle \mathrm{OA}$ concentration are largely driven by changes in the concentration of background (nonbiomass burning) OA. Some of the background OA concentration change is likely due to gas-to-particle partitioning changes that are themselves a function of OA concentration. In contrast to the AMS observations, there is no clear relationship between the PILS $\Delta$ levoglucosan $/ \Delta$ WSOC ratio and the $\Delta$ WSOC concentration (Fig. 8c).

MCE (modified combustion efficiency) can be used to investigate the role of fire dynamics. MCE is calculated as the excess carbon dioxide divided by the sum of the excess carbon monoxide and carbon dioxide $\left(\Delta \mathrm{CO}_{2} /(\Delta \mathrm{CO}\right.$ $\left.+\Delta \mathrm{CO}_{2}\right)$ ) on a molar basis (Ward and Radke, 1993). Therefore, a higher MCE value indicates emissions were 
dominated by flaming combustion whereas a lower value indicates more extensive contributions from smoldering. As seen in Fig. 9, there appears to be no clear dependence of the $\Delta$ levoglucosan / $\triangle \mathrm{WSOC}$ ratio on MCE. Overall, this finding is similar to the pattern observed for controlled laboratory burns, which covered the same dynamic range of MCE values, although the prescribed burns include a greater variety of MCE values for a particular fuel type. Therefore, it appears that source smoke marker ratios for prescribed burns are more dependent on the fuel type being burned than on differences in fire behavior.

\section{Summary}

Concentrations of smoke markers (e.g., levoglucosan and galactosan) are generally measured from ground-based, integrated filter samples. Here we took advantage of a new approach that permitted the first measurements of these compounds from an airborne platform. A PILS-TOC and fraction collector system was flown aboard a Twin Otter aircraft sampling prescribed burning emissions in South Carolina in November 2011. The PILS-TOC provided a $3 \mathrm{~s}$ timeintegrated measurement of WSOC. The fraction collector provided 2 min time-integrated samples to be analyzed offline for carbohydrates (i.e., smoke markers) by HPAECPAD. The HPAEC-PAD had ample sensitivity to detect levoglucosan, mannosan, and galactosan in the short-duration fraction collector samples. Comparisons with other measurements aboard the Twin Otter show that the 2 min time resolution was adequate to characterize smoke markers in the smoke plumes. The ability to collect quick samples with the PILS followed by later offline analysis provided advantages where rapid time resolution (minutes) is beneficial (i.e., plume sampling and/or aircraft measurements).

The ratio of $\Delta$ levoglucosan to $\triangle \mathrm{WSOC}$ varied across fires $\left(\mathrm{RF} 01 / \mathrm{RF} 02 / \mathrm{RF} 03 / \mathrm{RF} 05=0.163 \pm 0.007 \mu \mathrm{g} \mathrm{C} \mu \mathrm{g}^{-1} \mathrm{C}\right.$, $\mathrm{RF} 08=0.115 \pm 0.011 \mu \mathrm{g} \mathrm{C} \mu \mathrm{g}^{-1} \mathrm{C}, \mathrm{RF} 09 \mathrm{~A}=0.072$ $\pm 0.028 \mu \mathrm{g} \mathrm{C} \mu \mathrm{g}^{-1} \mathrm{C}$, and RF09B $=0.042 \pm 0.008 \mu \mathrm{g}$ $\left.\mathrm{C} \mu \mathrm{g}^{-1} \mathrm{C}\right)$. Available information about fire fuel type in the burns and a comparison of levoglucosan/WSOC ratios with laboratory burns of specific fuel types indicate the $\Delta$ levoglucosan / $\triangle \mathrm{WSOC}$ ratio differences are related to the mix of fuel types combusted in each fire. The comparison of prescribed vs. laboratory burn $\Delta$ galactosan / $\Delta$ levoglucosan ratios yields a consistent finding about the type of fuel involved in each fire. This was not, however, the case for $\Delta$ mannosan / $\Delta$ levoglucosan ratios, which could be due to a fuel element burned in the field, but not in the laboratory. A poor correlation of $\Delta$ potassium to $\Delta$ levoglucosan concentrations and large differences between values of this ratio observed in controlled laboratory burns and prescribed burns suggest that the laboratory burns may not yield representative potassium emissions. This result is not surprising given the known strong dependence of potassium emissions on fire flaming/smoldering ratios. No clear dependence of the $\Delta$ levoglucosan $/ \Delta \mathrm{WSOC}$ ratio on fire conditions, as represented by $\mathrm{MCE}$, was observed.

These results should help to better constrain apportionments and models trying to determine the impact of biomass burning on air quality. For example, it has been shown that source smoke marker ratios for levoglucosan and galactosan collected from controlled laboratory burns can be applied to obtain accurate estimates of the impacts of prescribed burning on fine particle concentrations. This is not the case for mannosan and potassium. Ratios for these species cannot accurately be drawn in all cases from controlled laboratory burns and should be site- and burn-specific. Knowledge of fuel-type-specific smoke marker profiles can improve both chemical transport model and receptor model estimates of prescribed burning impacts on fine particle concentrations and haze.

AMS measurements of smoke plumes aboard the aircraft also yielded interesting findings. A strong correlation between the AMS biomass burning marker at $\Delta m / z 60$ vs. $\triangle \mathrm{OA}$ was observed. This ratio did not vary with fuel type, but was positively correlated with $\triangle \mathrm{OA}$ at concentrations below $50 \mu \mathrm{g} \mathrm{m}^{-3}$. PMF analysis suggested that the concentration dependence of this ratio was largely driven by changes in the aerosol content of nonbiomass burning OA

Overall, this study demonstrated (1) a new capability for airborne, in-plume measurements of levoglucosan and other smoke marker concentrations, (2) a clear relationship between the $\Delta$ levoglucosan $/ \Delta \mathrm{WSOC}$ ratio and fuel type, and (3) the utility of AMS measurements of OA and $\mathrm{m} / \mathrm{z} 60$ as a quantitative method for apportioning biomass burning aerosol contributions to ambient aerosol, for several biomass fuel types sampled in this study.

\section{The Supplement related to this article is available online at doi:10.5194/acp-14-10535-2014-supplement.}

Acknowledgements. We acknowledge funding from the Joint Fire Science Program under Project JFSP 11-1-5-12 and the Strategic Environmental Research and Development Program (SERDP) project RC-1649. We thank R. J. Weber for generously providing some of the parts used in the PILS rack. We also thank E. J. T. Levin for his help in assembling the rack. We additionally acknowledge the Twin Otter Science Team, especially our pilot B. Mank and mechanic S. Woods. Lastly, special thanks to J. Maitland and his team at Fort Jackson, who conducted those burns, and the Columbia Dispatch Office of the South Carolina Forestry Commission for providing information on the additional burns.

Edited by: J. Thornton 


\section{References}

Aiken, A. C., Salcedo, D., Cubison, M. J., Huffman, J. A., DeCarlo, P. F., Ulbrich, I. M., Docherty, K. S., Sueper, D., Kimmel, J. R., Worsnop, D. R., Trimborn, A., Northway, M., Stone, E. A., Schauer, J. J., Volkamer, R. M., Fortner, E., de Foy, B., Wang, J., Laskin, A., Shutthanandan, V., Zheng, J., Zhang, R., Gaffney, J., Marley, N. A., Paredes-Miranda, G., Arnott, W. P., Molina, L. T., Sosa, G., and Jimenez, J. L.: Mexico City aerosol analysis during MILAGRO using high resolution aerosol mass spectrometry at the urban supersite (T0) - Part 1: Fine particle composition and organic source apportionment, Atmos. Chem. Phys., 9, 6633-6653, doi:10.5194/acp-9-6633-2009, 2009.

Akagi, S. K., Yokelson, R. J., Burling, I. R., Meinardi, S., Simpson, I., Blake, D. R., McMeeking, G. R., Sullivan, A., Lee, T., Kreidenweis, S., Urbanski, S., Reardon, J., Griffith, D. W. T., Johnson, T. J., and Weise, D. R.: Measurements of reactive trace gases and variable $\mathrm{O}_{3}$ formation rates in some South Carolina biomass burning plumes, Atmos. Chem. Phys., 13, 1141-1165, doi:10.5194/acp-13-1141-2013, 2013.

Burling, I. R., Yokelson, R. J., Griffith, D. W. T., Johnson, T. J., Veres, P., Roberts, J. M., Warneke, C., Urbanski, S. P., Reardon, J., Weise, D. R., Hao, W. M., and de Gouw, J.: Laboratory measurements of trace gas emissions from biomass burning of fuel types from the southeastern and southwestern United States, Atmos. Chem. Phys., 10, 11115-11130, doi:10.5194/acp10-11115-2010, 2010.

Burling, I. R., Yokelson, R. J., Akagi, S. K., Urbanski, S. P., Wold, C. E., Griffith, D. W. T., Johnson, T. J., Reardon, J., and Weise, D. R.: Airborne and ground-based measurements of the trace gases and particles emitted by prescribed fires in the United States, Atmos. Chem. Phys., 11, 12197-12216, doi:10.5194/acp11-12197-2011, 2011.

DeCarlo, P. F., Kimmel, J. R., Trimborn, A., Northway, M. J., Jayne, J. T., Aiken, A. C., Gonin, M., Fuhrer, K., Horvath, T., Docherty, K. S., Worsnop, D. R., and Jimenez, J. L.: Fielddeployable, high-resolution, time-of-flight aerosol mass spectrometer, Anal. Chem., 78, 8281-8289, 2006.

Eatough, D. J., Wadsworth, A., Eatough, D. A., Crawford, J. W., Hansen, L. D., and Lewis, E. A.: A multiple system, multichannel diffusion denuder sampler for the determination of fineparticulate organic material in the atmosphere, Atmos. Environ., 27, 1213-1219, 1993.

Echalar, F., Gaudichet, A., Cachier, H., and Artaxo, P.: Aerosol emissions by tropical forest and savanna biomass burning: characteristic trace elements and fluxes, Geophys. Res. Lett., 22, 3039-3042, 1995.

Engling, G., Carrico, C. M., Kreidenweis, S. M., Collett Jr., J. L., Day, D. E., Malm, W. C., Lincoln, E., Hao, W. M., Iinuma, Y., and Herrmann, H.: Determination of levoglucosan in biomass combustion aerosol by high-performance anion-exchange chromatography with pulsed amperometric detection, Atmos. Environ., 40, S299-S311, 2006.

Eom, I.-Y., Kim, J.-Y., Kim, T.-S, Lee, S.-M., Choi, D., Choi, I.G., and Choi, J.-W.: Effect of essential inorganic metals on primary thermal degradation of lignocellulosic biomass, Bioresource Technol., 104, 687-694, 2012.

Fine, P. M., Cass, G. R., and Simoneit, B. R. T.: Chemical characterization of fine particle emissions from the fireplace combus- tion of wood types grown in the midwestern and western United States, Environ. Eng. Sci., 21, 387-409, 2004.

Fraser, M. P., Yue, Z. W., and Buzcu, B.: Source appointment of fine particulate matter in Houston, TX, using organic molecular markers, Atmos. Environ., 37, 2117-2123, 2003.

Gao, S., Hegg, D. A., Hobbs, P. V., Kirchstetter, T. W., Magi, B. I., and Sadilek, M.: Water-soluble organic components in aerosols associated with savanna fires in southern Africa: identification, evolution, and distribution, J. Geophys. Res., 108, 8491, doi:10.1029/2002JD002324, 2003.

Gorin, C. A., Collett Jr., J. L., and Herckes, P.: Wood smoke contribution to winter aerosol in Fresno, CA, J. Air Waste Manage., 56, 1584-1590, 2006.

Hays, M. D., Geron, C. D., Linna, K. J., Smith, N. D., and Schauer, J. J.: Speciation of gas-phase and fine particle emissions from burning of foliar fuels, Environ. Sci. Technol., 36, 2281-2295, 2002.

Lee, S., Baumann, K., Schauer, J. J., Sheesley, R. J., Naeher, L. P., Meinardi, S., Blake, D. R., Edgerton, E. S., Russell, A. G., and Clements, M.: Gaseous and particulate emissions from prescribed burning in Georgia, Environ. Sci. Technol., 39, 90499056, 2005.

Lee, T., Sullivan, A. P., Mack, L., Jimenez, J. L., Kreidenweis, S. M., Onasch, T. B., Worsnop, D. R., Malm, W., Wold, C. E., Hao, W. M., and Collett Jr., J. L.: Chemical smoke marker emissions during flaming and smoldering phases of laboratory open burning of wildland fuels, Aerosol Res. Lett., 44, i-v, 2010.

Marple, V. A., Rubow, K. L., and Behm, S. M.: A microorifice uniform deposit impactor (MOUDI): description, calibration, and use, Aerosol Sci. Tech., 14, 434-446, 1991.

May, A. A., Lee, T., McMeeking, G. R., Akagi, S., Sullivan, A. P., Urbanski, S., Yokelson, R. J., and Kreidenweis, S. M.: Investigation of Chemical and Physical Perturbations to Organic Aerosol Present in Biomass Burning Plumes over Prescribed Fires in South Carolina, Atmos. Chem. Phys., in preparation, 2014a.

May, A. A., McMeeking, G. R., Lee, T., Taylor, J. W., Craven, J. S., Burling, I., Sullivan, A. P., Akagi, S., Collett Jr., J. L., Flynn, M., Coe, H., Urbanski, S. P., Seinfeld, J. H., Yokelson, R. J., and Kreidenweis, S. M.: Aerosol emissions from prescribed fires in the United States: A synthesis of laboratory and aircraft measurements, J. Geophys. Res., accepted, doi:10.1002/2014JD021848, 2014b.

Mazzoleni, L. R., Zielinska, B., and Moosmüller, H.: Emissions of levoglucosan, methoxy phenols, and organic acids from prescribed burns, laboratory combustion of wildland fuels, and residential wood combustion, Environ. Sci. Technol., 41, 21152122, 2007.

Mohr, C., Huffman, J. A., Cubison, M. J., Aiken, A. C., Docherty, K. S., Kimmel, J. R., Ulbrich, I. M., Hannigan, M., and Jimenez, J. L.: Characterization of primary organic aerosol emissions from meat cooking, trash burning, and motor vehicles with high-resolution aerosol mass spectrometry and comparison with ambient and chamber observations, Environ. Sci. Technol., 43, 2443-2449, 2009.

Orsini, D. A., Ma, Y., Sullivan, A., Sierau, B., Baumann, K., and Weber, R. J.: Refinements to the particle-into-liquid sampler (PILS) for ground and airborne measurements of water-soluble aerosol composition, Atmos. Environ., 37, 1243-1259, 2003. 
Patwardhan, P. R., Satrio, J. A., Brown, R. C., and Shanks, B. H.: Influence of inorganic salts on the primary pyrolysis products of cellulose, Bioresource Technol., 101, 4646-4655, 2010.

Puxbaum, H., Caseiro, A., Sánchez-Ochoa, A., Kasper-Giebl, A., Claeys, M., Gelencsér, A., Legrand, M., Preunkert, S., and Pio, C.: Levoglucosan levels at background sites in Europe for assessing the impact of biomass combustion on the European aerosol background, J. Geophys. Res., 112, D23S05, doi:10.1029/2006JD008114, 2007.

Radlein, D., Piskorz, J., and Scott, D. S.: Fast pyrolysis of natural polysaccharides as a potential industrial process, J. Anal. Appl. Pyrol., 19, 41-63, 1991.

Richards, G. N. and Zheng, G.: Influence of metal ions and of salts on products from pyrolysis of wood: applications to thermochemical processing of newsprint and biomass, J. Anal. Appl. Pyrol., 21, 133-146, 1991.

Rinehart, L. R., Fujita, E. M., Chow, J. C., Magliano, K., and Zielinska, B.: Spatial distribution of $\mathrm{PM}_{2.5}$ associated organic compounds in central California, Atmos. Environ., 40, 290-303, 2006

Schauer, J. J. and Cass, G. R.: Source apportionment of wintertime gas-phase and particle-phase air pollutants using organic compounds as tracers, Environ. Sci. Technol., 34, 1821-1832, 2000.

Schauer, J. J., Rogge, W. F., Hildemann, L. M., Mazurek, M. A., and Cass, G. R.: Source apportionment of airborne particulate matter using organic compounds as tracers, Atmos. Environ., 30, 3837-3855, 1996.

Sorooshian, A., Brechtel, F. J., Ma, Y., Weber, R. J., Corless, A., Flagan, R. C., and Seinfeld, J. H.: Modeling and characterization of a Particle-into-Liquid Sampler (PILS), Aerosol Sci. Tech., 40, 396-409, 2006.

Sullivan, A. P., Weber, R. J., Clements, A. L., Turner, J. R., Bae, M. S., and Schauer, J. J.: A method for on-line measurement of water-soluble organic carbon in ambient aerosol particles: recent results from an urban site, Geophys. Res. Lett., 31, L13105, doi:10.1029/2004GL019681, 2004.

Sullivan, A. P., Peltier, R. E., Brock, C. A., de Gouw, J. A., Holloway, J. S., Warneke, C., Wollny, A. G., and Weber, R. J.: Airborne measurements of carbonaceous aerosol soluble in water over northeastern United States: method development and an investigation into water-soluble organic carbon sources, J. Geophys. Res., 111, D23S46, doi:10.1029/2006JD007072, 2006.

Sullivan, A. P., Holden, A. S., Patterson, L. A., McMeeking, G. R., Kreidenweis, S. M., Malm, W. C., Hao, W. M., Wold, C. E., and Collett Jr., J. L.: A method for smoke marker measurements and its potential application for determining the contribution of biomass burning from wildfires and prescribed fires to ambient $\mathrm{PM}_{2.5}$ organic carbon, J. Geophys. Res., 113, D22302, doi:10.1029/2008JD010216, 2008.
Sullivan, A. P., Frank, N., Onstad, G., Simpson, C. D., and Collett Jr., J. L.: Application of high-performance anion-exchange chromatography - pulsed amperometric detection for measuring carbohydrates in routine daily filter samples collected by a national network: 1 . Determination of the impact of biomass burning in the upper midwest, J. Geophys. Res., 116, D08302, doi:10.1029/2010JD014166, 2011a.

Sullivan, A. P., Frank, N., Kenski, D. M., and Collett Jr., J. L.: Application of high-performance anion-exchange chromatography - pulsed amperometric detection for measuring carbohydrates in routine daily filter samples collected by a national network: 2. Examination of sugar alcohols/polyols, sugars, and anhydrosugars in the upper midwest, J. Geophys. Res., 116, D08303, doi:10.1029/2010JD014169, 2011b.

Sullivan, A. P., Kreidenweis, S. M., Schichtel, B. A., and Collett Jr., J. L.: Source Smoke Marker Ratios from Controlled Laboratory Burns vs. Prescribed Burns and Wildfires, Atmos. Chem. Phys., in preparation, 2014.

Ward, D. E. and Radke, L. F.: Emission measurements from vegetation fires: a comparative evaluation of methods and results, in: Fire in the Environment: the Ecological, Atmospheric, and Climatic Importance of Vegetation Fires, edited by: Crutzen, P. J. and Goldammer, J. G., Wiley, Chichester, England, 53-76, 1993.

Ward, D. E., Setzer, A. W., Kaufman, Y. J., and Rasmussen, R. A.: Characteristics of smoke emissions from biomass fires of the Amazon region - BASE - a experiment, in: Global Biomass Burning: Atmospheric, Climatic, and Biospheric Implications, edited by: Levine, J. S., MIT Press, Cambridge, MA, 394-402, 1991.

Wilson, J. C., Lafleur, B. G., Hilbert, H., Seebaugh, W. R., Fox, J., Gesler, D. W., Brock, C. A., Huebert, B. J., and Mullen, J.: Function and performance of a low turbulence inlet for sampling supermicron particles from aircraft platforms, Aerosol Sci. Tech., 38, 790-802, 2004.

Yokelson, R. J., Goode, J. G., Ward, D. E., Susott, R. A., Babbitt, R. E., Wade, D. D., Bertschi, I., Griffith, D. W. T., and Hao, W. M.: Emissions of formaldehyde, acetic acid, methanol, and other trace gases from biomass fires in North Carolina measured by airborne Fourier transform infrared spectroscopy, J. Geophys. Res., 104, D23, 30109-30126, doi:10.1029/1999JD900817, 1999.

Yokelson, R. J., Burling, I. R., Gilman, J. B., Warneke, C., Stockwell, C. E., de Gouw, J., Akagi, S. K., Urbanski, S. P., Veres, P., Roberts, J. M., Kuster, W. C., Reardon, J., Griffith, D. W. T., Johnson, T. J., Hosseini, S., Miller, J. W., Cocker III, D. R., Jung, H., and Weise, D. R.: Coupling field and laboratory measurements to estimate the emission factors of identified and unidentified trace gases for prescribed fires, Atmos. Chem. Phys., 13, 89-116, doi:10.5194/acp-13-89-2013, 2013. 